\title{
Performance of low-fat beef burger with added soluble and insoluble dietary fibers
}

\author{
Camila Vespúcio BIS-SOUZA ${ }^{1}$, Jenifer Mayara Monari HENCK ${ }^{1}$, Andrea Carla da Silva BARRETTO ${ }^{1 \star}$
}

\begin{abstract}
Inulin, fructooligosaccharide, oat fiber and wheat fiber were added at 3 and $6 \%$ level in low-fat beef burger and their performances were evaluated. The low-fat beef burgers were submitted to cooking losses, objective color, texture profile, TBARS value, $\mathrm{pH}$, microbiological and sensory evaluations. FR3, FR6, IN3 e IN6 showed no difference from the control to yield. Hardness values increased in OF6, WF3 and WF6 and it was similar to control. WF6 was the lowest score for the overall acceptance. Higher yield and hardness were found with the addition of insoluble fibers at $6 \%$ level. The TBARS values were not influenced by the addition of dietary fibers in low-fat beef burger. Inulin at 6\% (IN6) level showed the highest score for all the sensory attributes. Adding $6 \%$ inulin was shown the best alternative for use in low-fat beef burger.
\end{abstract}

Keywords: dietary fiber; acceptability; fat substitute; TPA; inulin.

Practical Application: Comparison of technology behavior of soluble and insoluble fiber as fat substitute in beef burger.

\section{Introduction}

Fat intake is associated with increased risk of illness, such as obesity, coronary heart disease and some types of cancer (Weiss et al., 2010). Meat and meat products when consumed in inappropriate quantities may enhance these diseases (Saldaña et al., 2014; Cofrades et al., 2016). The incorporation of dietary fiber in low-fat meat products has been suggested to reduce the saturated fat level and also to increase the fiber content of the final product (Elleuch et al., 2011; Talukder, 2015). Several authors have been shown that the addition of dietary fiber in the processing of low-fat meat products may increase the water retention and the yield (Shariati-Ievari et al., 2016). These products show similar sensory characteristics compared to the traditional products (Mansour \& Khalil, 1999; Fernández-Ginés et al., 2004; Borderías et al., 2005; Yoo et al., 2007; Piñero et al., 2008; Decker \& Park, 2010; Sánchez-Zapata et al., 2010; Huang et al., 2011; Álvarez \& Barbut, 2013; Schmiele et al., 2015; Selani et al., 2016).

Classification of dietary fiber as soluble and insoluble creates differences in the technological properties and physiological effects (Verma \& Banerjee, 2010). Soluble fibers, such as inulin and fructooligosaccharide decrease the concentration of LDL cholesterol in the blood, which prevents the development of chronic noncommunicable diseases (NCDs) (Hauly \& Moscatto, 2002). Insoluble fibers, such as oat fiber and wheat fiber provide protection from colon cancer, and they are used in the treatment of constipation and other related diseases, as well as for regulating of body weight (Drzikova et al., 2005).

Fructooligosaccharides are constituted of chains with a degree of polymerization (DP) of 3 to 10 units, while inulin shows DP of 2 to 60 units. This causes differences in the functional and technological attributes of these compounds (Hauly \& Moscatto, 2002). These soluble fibers show ability to increase viscosity and gel forming ability without affecting the texture and taste of the product (Álvarez \& Barbut, 2013). Oat fiber and wheat fiber increase the capacity of water and fat retention and they can improve the yield avoiding water loss during cooking (Elleuch et al., 2011). Thus, the aim of this work was to evaluate the effects of two soluble fibers (fructooligosaccharide and inulin) and two insoluble fibers (oat fiber and wheat fiber) on physicochemical and sensory properties in low-fat beef burger at 3 and $6 \%$ level, and compare the performance obtained.

\section{Materials and methods}

\subsection{Beef burger manufacture}

Fresh beef (moisture $72 \%$, fat $4 \%$ ) and pork back fat (moisture $19 \%$, fat $71 \%$ ) ground using 0.5 and $0.8 \mathrm{~cm}$ plates respectively, provided by an industrial supplier (Frigorífico Olhos D’água, Ipuã, SP, Brazil) which has a Federal Inspection Service. Two soluble dietary fibers were used: Orafti ${ }^{\circledR}$ inulin (moisture $3 \%$; total dietary fiber 90\%) from Clariant (São Paulo, SP, Brazil) and fructooligosaccharide (moisture 4\%; total dietary fiber 95\%) from Ingredion ${ }^{\circledR}$ (Mogi Guaçu, SP, Brazil) and two insoluble fibers: oat fiber (moisture 7\%; total dietary fiber 96\%) from JRS Rettenmeyer $^{\circledR}$ (São Paulo, SP, Brazil) and wheat fiber (moisture $6 \%$; total dietary fiber $96 \%$ ) from Nutrassim ${ }^{\circledR}$ (Extrema, MG, Brazil). The low-fat beef burger with added dietary fibers and control treatments were processed in a pilot plant for meat products following good manufacturing practice. All the ingredients were mixed manually for approximately 5 minutes 
and, after that $100 \mathrm{~g}$ portion were molded using a burger-maker (with $11 \mathrm{~cm}$ diameter), packed in plastic bags and frozen individually. The treatments were kept in the freezer at $-18^{\circ} \mathrm{C}$ during the analysis ( 90 days). All the treatments used the following ingredients: $70.00 \%$ beef; $1.50 \%$ salt; $0.05 \%$ sodium erythorbate; $0.15 \%$ monosodium glutamate; $0.20 \%$ white pepper. Table 1 shows the amount of pork back fat, ice water and dietary fiber added in each treatment. The experiments were carried out in three independent replicates of each batch.

\subsection{Proximate composition analysis}

All the treatments were characterized for moisture, protein, and ash content according to Horwitz \& Latimer (2007) and the fat content was determined according to Bligh \& Dyer's (1959). Available carbohydrates were calculated by difference. All analysis was performed in triplicate.

\subsection{Physicochemical analysis}

The $\mathrm{pH}$ was determined immediately after completing manufacturing (day 0 ) and after 90 days of frozen storage. The $\mathrm{pH}$ was measured in triplicate in each treatment using a digital pH meter PG 1800 (Gehaka, São Paulo, SP, Brazil) with a penetration probe as described previously (Barretto et al., 2015). The equipment was calibrated with two standard solutions ( $\mathrm{pH} 4$ and $\mathrm{pH} 7$ ) at room temperature. The color evaluation was performed on the raw low-fat beef burger with added dietary fibers and controls, after defrosting at refrigerated temperature for 24 hours, using a spectrophotometer, model ColorFlex45/0 (Hunterlab, Reston, VA, USA), observation angle of $10^{\circ}$, illuminant D65 and Universal software version 4.10. The specification system used was CIELAB color (Tapp et al., 2011) and the color coordinates determined were lightness ( $L^{*}$ value), redness ( $\mathrm{a}^{\star}$ value) and yellowness ( $\mathrm{b}^{\star}$ value). This analysis was performed after 30, 60 and 90 days of frozen storage, with five readings for each sample.

\subsection{Cooking properties}

All the treatments were placed in baking sheets covered with foil and cooked in industrial kiln (Pasiani, São Paulo, Brazil) at $150^{\circ} \mathrm{C}$ for 15 minutes, until the internal temperature was $72^{\circ} \mathrm{C}$. The yield (Equation 1) and shrinkage (Equation 2) were calculated according to Sánchez-Zapata et al. (2010):
$\%$ Yield $=\left(\frac{\text { cooked weight }}{\text { rawweight }}\right) \times 100$

$\%$ Shrinkage $=\left(\frac{\text { rawdiameter }- \text { cooked diameter }}{\text { rawdiameter }}\right) \times 100$

Texture profile analysis (TPA) was performed on the cooked low-fat beef burger with added dietary fibers and the controls using a Texture Analyzer TA-XT Plus (Godalming, England) according to the methodology described by Bourne (2002). The samples were cut in circular mold with $2 \mathrm{~cm}$ diameter after cooking and cooling at room temperature. All treatments were compressed to $50 \%$ of their original height with a cylindrical probe of $2.5 \mathrm{~cm}$ diameter, with a test speed of $1 \mathrm{~mm} \mathrm{~s}^{-1}$. This was repeated six times for each treatment. Texture profile parameters determined: hardness (maximum force required to compress the sample), cohesiveness (extent to which the sample could be deformed prior to rupture - $A_{2} / A_{1}, A_{1}$ was the total energy required for the first compression and $A_{2}$ the total energy required for the second compression), springiness (ability of sample to recover its original form after the deforming force was removed) and chewiness (work to masticate the sample for swallowing) (Bourne, 2002). The analyses were performed with cooked samples at room temperature. Lipid oxidation was assessed in the raw low-fat beef burger with added dietary fibers and controls following the recommendations described by Vyncke (1970). The TBARS value was measured from a standard curve of malonaldehyde (MA) and expressed as mg MA kg of sample ${ }^{-1}$. The analyses were performed in triplicate. The TBARS index was assessed immediately after completing manufacturing (day 0$)$ and after 30, 60 e 90 days of frozen storage.

\subsection{Microbiological analysis}

The microbiological analysis was performed with control and treatment according to the limits established by the Brazilian Legislation (Brazilian Health Surveillance Agency - ANVISA, BRAZIL) to verify the hygienic quality of the sample. All the treatments were thawed for 24 hours at refrigeration temperature $\left(4^{\circ} \mathrm{C}\right)$ and $25 \mathrm{~g}$ of the sample was diluted in $225 \mathrm{~mL}$ of sterile peptone water (HIMEDIA, Mumbai, India) for investigation of thermotolerant coliforms, coagulase-positive Staphylococci and sulfite-reducing clostridia. The presence of Salmonella sp. in $25 \mathrm{~g}$ of sample was determined using the dilution in $225 \mathrm{~mL}$ of lactose broth (HIMEDIA, Mumbai, India) (Horwitz \& Latimer,

Table 1. Amounts of pork back fat, ice water and dietary fiber (\%).

\begin{tabular}{|c|c|c|c|c|c|c|c|c|c|c|}
\hline & $\mathrm{C} 1$ & $\mathrm{C} 2$ & FR3 & FR6 & IN3 & IN6 & OF3 & OF6 & WF3 & WF6 \\
\hline Pork back fat & 20.00 & 10.00 & 10.00 & 10.00 & 10.00 & 10.00 & 10.00 & 10.00 & 10.00 & 10.00 \\
\hline Ice water & 8.10 & 18.10 & 15.10 & 12.10 & 15.10 & 12.10 & 15.10 & 12.10 & 15.10 & 12.10 \\
\hline Fructooligosaccharide & - & - & 3.00 & 6.00 & - & - & - & - & - & - \\
\hline Oat fiber & - & - & - & - & - & - & 3.00 & 6.00 & - & - \\
\hline Wheat fiber & - & - & - & - & - & - & - & - & 3.00 & 6.00 \\
\hline
\end{tabular}

C1, 100\% pork back fat and no added dietary fiber; C2, 50\% pork back fat and no added dietary fiber; FR3, 50\% pork back fat and 3\% fructooligosaccharide; FR6, 50\% pork back fat and $6 \%$ fructooligosaccharide; IN3, 50\% pork back fat and 3\% inulin; IN6, 50\% pork back fat and 6\% inulin; OF3, 50\% pork back fat and 3\% oat fiber; OF6, $50 \%$ pork back fat and $6 \%$ oat fiber; WF3, $50 \%$ pork back fat and $3 \%$ wheat fiber; WF6, $50 \%$ pork back fat and $6 \%$ wheat fiber. 
2007). Thermotolerant coliforms were identified using the multiple-tube fermentation test and expressed as most probable number (MPN) g sample ${ }^{-1}$. Coagulase-positive Staphylococci were identified by inoculating samples in Baird Parker Agar (HIMEDIA, Mumbai, India) enriched egg yolk and potassium tellurite $1 \%$. Sulfite-reducing clostridia were counted by inoculating samples in SPS Agar (HIMEDIA, Mumbai, India) in anaerobic jars (Horwitz \& Latimer, 2007). All these measurements were done in duplicate and the results were expressed in log CFU g of sample ${ }^{-1}$.

\subsection{Sensory analysis}

The acceptability test was performed at the Sensory Analysis Laboratory of the Department of Food Technology and Engineering (UNESP, São José do Rio Preto, SP, Brazil) near to 30 days of frozen storage. The panel consisted of 74 non-trained panelists of staff and students from the university. The Ethics Committee of Research of the UNESP (São José do Rio Preto, Brazil) approved the sensory analysis of control and low-fat beef burger. The process number was $n^{\circ} 948.501$. Samples were cooked at $72{ }^{\circ} \mathrm{C}$ internal temperature, then maintained at an average temperature of $60^{\circ} \mathrm{C}$ in a water bath at $90^{\circ} \mathrm{C}$ (until the moment of analysis). Each sample was coded with a three-digit number and the presentation was randomized in a sequential monadic way, following a balanced complete block design. The sensory test was held in two sessions, five samples each. All panelists evaluated one samples of all treatments in a randomized order. It was provided unsalted crackers and water at room temperature to clean the palate between each sample. A nine-point hedonic scale $(1=$ extremely disliked and $9=$ =xtremely liked $)$ was used and the four attributes evaluated were color, taste, texture and overall acceptance.

\subsection{Statistical data analysis}

The study was a randomized block design with ten treatments. Each experiment was replicated three times and the measurements lasted 90 days. The data obtained on physicochemical properties were analyzed statistically using one-way analysis of variance (ANOVA) with the treatment as fixed factor and the batches as random effects. Mean comparisons were assessed by the Tukey test at a confidence level of $95 \%(\mathrm{P}>0.05)$. The software used was Minitab (version 16) (Minitab Inc, University Park, PA, USA,). The sensory experiment was analyzed using one-way analysis of variance (ANOVA) with panelist as random factor and treatments as fixed effects. The principal component analysis (PCA) determined the correlation between the variables related to the technological characteristics of the cooked samples (cooking properties, sensory attributes, texture profile analysis), using a correlation matrix. The software used in this analysis was STATISTICA (StatSoft, Inc. version 7.0).

\section{Results and discussion}

\subsection{Proximate analysis of beef burgers}

The content of ash and protein was similar $(\mathrm{P}>0.05)$ for all the treatments (Table 2).

This is justifiable by the fact that all the treatments used the same raw material in the same amounts. Results found were with in Brazilian standards for the identity and quality of burger (Brasil, 2000) - minimum protein content: 15\% for and maximum fat content: $23 \%$. Moisture content shows a significant difference $(\mathrm{P}>0.05)$ between the controls where $\mathrm{C} 1$ presented the lowest value and $\mathrm{C} 2$ the highest (Table 2). This difference observed in the moisture content might be due to the amount of water added in each formulation (Table 1). The treatment with $6 \%$ of inulin added (IN6) and oat fiber (OF6) showed moisture content similar to the control $(\mathrm{C} 1)$. Fat content showed a reduction around $50 \%(\mathrm{P}<0.05)$ as compared to control $\mathrm{C} 1$ with $\mathrm{C} 2$ and the other treatments.

There was an increase in the carbohydrates content in the low-fat beef burger with added dietary fiber when compared to the control. The addition of 3 and $6 \%$ of insoluble dietary fiber caused a significant reduction $(\mathrm{P}>0.05)$ in $\mathrm{pH} 0$ day value (Table 3). However, after 90 days of storage all the treatment and

Table 2. Composition (\%) of low-fat beef burger with dietary fibers and controls.

\begin{tabular}{|c|c|c|c|c|c|}
\hline Treatments & Moisture & Ash & Protein & Fat & Carbohydrate $^{*}$ \\
\hline $\mathrm{C} 1$ & $63.5 \pm 0.0^{\mathrm{d}}$ & $2.1 \pm 0.0^{\mathrm{a}}$ & $17.0 \pm 0.1^{\mathrm{a}}$ & $13.2 \pm 0.3^{\mathrm{a}}$ & 4.3 \\
\hline $\mathrm{C} 2$ & $69.2 \pm 0.1^{\mathrm{a}}$ & $2.1 \pm 0.0^{\mathrm{a}}$ & $17.4 \pm 0.4^{\mathrm{a}}$ & $6.7 \pm 0.4^{\mathrm{b}}$ & 4.6 \\
\hline FR3 & $68.0 \pm 0.5^{\mathrm{ab}}$ & $2.1 \pm 0.0^{\mathrm{a}}$ & $16.8 \pm 0.4^{\mathrm{a}}$ & $6.7 \pm 0.2^{b}$ & 6.4 \\
\hline FR6 & $65.5 \pm 0.4^{\mathrm{bcd}}$ & $2.2 \pm 0.0^{\mathrm{a}}$ & $16.9 \pm 0.2^{\mathrm{a}}$ & $7.0 \pm 1.0^{\mathrm{b}}$ & 9.3 \\
\hline IN3 & $65.0 \pm 0.5^{\mathrm{bcd}}$ & $2.1 \pm 0.2^{\mathrm{a}}$ & $16.9 \pm 0.2^{\mathrm{a}}$ & $7.5 \pm 0.8^{\mathrm{b}}$ & 7.8 \\
\hline IN6 & $64.5 \pm 0.5^{\mathrm{d}}$ & $2.0 \pm 0.0^{\mathrm{a}}$ & $16.2 \pm 0.1^{\mathrm{a}}$ & $7.3 \pm 0.4^{\mathrm{b}}$ & 10.0 \\
\hline OF3 & $65.8 \pm 0.6^{\mathrm{bcd}}$ & $2.1 \pm 0.0^{\mathrm{a}}$ & $17.0 \pm 0.0^{\mathrm{a}}$ & $7.8 \pm 0.5^{b}$ & 7.9 \\
\hline OF6 & $64.8 \pm 0.7^{\mathrm{d}}$ & $2.0 \pm 0.0^{\mathrm{a}}$ & $17.1 \pm 0.3^{\mathrm{a}}$ & $6.5 \pm 0.4^{\mathrm{b}}$ & 9.5 \\
\hline WF3 & $67.7 \pm 0.7^{\mathrm{abc}}$ & $2.1 \pm 0.0^{\mathrm{a}}$ & $16.7 \pm 0.4^{\mathrm{a}}$ & $7.4 \pm 0.7^{\mathrm{b}}$ & 6.2 \\
\hline WF6 & $65.2 \pm 0.0^{\mathrm{cd}}$ & $2.2 \pm 0.0^{\mathrm{a}}$ & $17.2 \pm 0.3^{\mathrm{a}}$ & $6.6 \pm 0.4^{\mathrm{b}}$ & 8.9 \\
\hline
\end{tabular}

Means \pm standard deviation. Different letters in the same column differ significantly $(\mathrm{P}<0.05)$ by the Tukey's test. C1, $100 \%$ pork back fat and no added dietary fiber; $\mathrm{C} 2,50 \%$ pork back fat and no added dietary fiber; FR3, 50\% pork back fat and 3\% fructooligosaccharide; FR6, 50\% pork back fat and 6\% fructooligosaccharide; IN3, 50\% pork back fat and 3\% inulin; IN6, $50 \%$ pork back fat and $6 \%$ inulin; OF3, $50 \%$ pork back fat and $3 \%$ oat fiber; OF6, $50 \%$ pork back fat and $6 \%$ oat fiber; WF3, 50\% pork back fat and $3 \%$ wheat fiber; WF $6,50 \%$ pork back fat and $6 \%$ wheat fiber.

${ }^{*}$ carbohydrate determined by difference. 
Table 3. Instrumental color and $\mathrm{pH}$ of low-fat beef burger with dietary fibers and controls.

\begin{tabular}{|c|c|c|c|c|c|c|c|c|c|c|}
\hline & $\mathrm{C} 1$ & $\mathrm{C} 2$ & FR3 & FR6 & IN3 & IN6 & OF3 & OF6 & WF3 & WF6 \\
\hline$L^{*} 30$ & $49.2 \pm 2.1^{\mathrm{a}}$ & $47.6 \pm 1.7^{\mathrm{ab}}$ & $45.1 \pm 2.6^{c}$ & $42.9 \pm 2.0^{c}$ & $45.3 \pm 2.7^{\mathrm{bc}}$ & $46.3 \pm 3.5^{c}$ & $46.6 \pm 1.6^{\mathrm{abc}}$ & $48.8 \pm 3.3^{\mathrm{ab}}$ & $46.9 \pm 1.2^{\mathrm{ab}}$ & $47.6 \pm 3.9^{\mathrm{ab}}$ \\
\hline$L^{\star} 60$ & $53.1 \pm 1.9^{\mathrm{a}}$ & $48.1 \pm 4.5^{\mathrm{b}}$ & $49.2 \pm 1.2^{\mathrm{ab}}$ & $49.5 \pm 1.7^{\mathrm{ab}}$ & $50.1 \pm 2.9^{\mathrm{ab}}$ & $48.4 \pm 2.5^{\mathrm{b}}$ & $47.5 \pm 0.8^{\mathrm{b}}$ & $49.5 \pm 1.0^{\mathrm{ab}}$ & $48.1 \pm 0.9^{\mathrm{b}}$ & $50.6 \pm 1.6^{\mathrm{ab}}$ \\
\hline$L^{*} 90$ & $54.5 \pm 1.6^{\mathrm{a}}$ & $46.5 \pm 0.6^{\text {cdef }}$ & $44.1 \pm 2.8^{\mathrm{e}}$ & $45.4 \pm 1.3^{\mathrm{de}}$ & $51.8 \pm 0.9^{\mathrm{ab}}$ & $47.3 \pm 1.3^{\text {cde }}$ & $45.8 \pm 1.8^{\mathrm{bcd}}$ & $49.2 \pm 2.3^{\mathrm{ab}}$ & $47.6 \pm 0.5^{\mathrm{cd}}$ & $49.3 \pm 1.2^{\mathrm{bc}}$ \\
\hline$a^{\star} 60$ & $12.0 \pm 1.8^{\mathrm{b}}$ & $12.6 \pm 2.7^{\mathrm{b}}$ & $12.2 \pm 0.2^{\mathrm{b}}$ & $12.5 \pm 0.4^{\mathrm{b}}$ & $11.8 \pm 0.7^{\mathrm{b}}$ & $12.5 \pm 1.7^{\mathrm{b}}$ & $16.3 \pm 0.6^{\mathrm{a}}$ & $11.6 \pm 0.4^{\mathrm{b}}$ & $13.1 \pm 0.4^{\mathrm{b}}$ & $13.2 \pm 0.6^{b}$ \\
\hline$a^{\star} 90$ & $9.4 \pm 0.4^{\mathrm{d}}$ & $12.2 \pm 0.7^{\mathrm{b}}$ & $12.9 \pm 1.2^{\mathrm{ab}}$ & $12.7 \pm 0.4^{\mathrm{ab}}$ & $8.4 \pm 0.8^{\mathrm{d}}$ & $9.9 \pm 1.0^{\mathrm{cd}}$ & $14.3 \pm 0.8^{\mathrm{a}}$ & $14.3 \pm 1.4^{\mathrm{bc}}$ & $9.8 \pm 0.9^{c d}$ & $11.4 \pm 0.5^{b c}$ \\
\hline$b^{\star} 90$ & $15.7 \pm 0.7^{\mathrm{abcd}}$ & $15.3 \pm 0.7^{\mathrm{bcd}}$ & $14.7 \pm 0.7^{\mathrm{d}}$ & $15.1 \pm 0.9^{\mathrm{cd}}$ & $13.1 \pm 0.5^{\mathrm{e}}$ & $14.6 \pm 0.5^{\mathrm{d}}$ & $16.8 \pm 0.3^{\mathrm{a}}$ & $16.6 \pm 0.6^{\mathrm{ab}}$ & $15.5 \pm 0.4^{\mathrm{d}}$ & $16.3 \pm 0.4^{\mathrm{abc}}$ \\
\hline pH 0 & $6.1 \pm 0.3^{\mathrm{a}}$ & $6.1 \pm 0.1^{\mathrm{a}}$ & $5.9 \pm 0.1^{\mathrm{ab}}$ & $5.7 \pm 0.2^{\mathrm{ab}}$ & $5.8 \pm 0.2^{\mathrm{ab}}$ & $5.9 \pm 0.1^{\mathrm{ab}}$ & $5.8 \pm 0.1^{\mathrm{ab}}$ & $5.7 \pm 0.1^{\mathrm{b}}$ & $5.8 \pm 0.1^{\mathrm{ab}}$ & $5.7 \pm 0.3^{\mathrm{b}}$ \\
\hline pH 90 & $6.1 \pm 0.2^{\mathrm{a}}$ & $6.1 \pm 0.1^{\mathrm{a}}$ & $6.1 \pm 0.2^{\mathrm{a}}$ & $6.1 \pm 0.2^{\mathrm{a}}$ & $6.1 \pm 0.7^{\mathrm{a}}$ & $6.1 \pm 0.2^{\mathrm{a}}$ & $6.2 \pm 0.2^{\mathrm{a}}$ & $6.2 \pm 0.2^{\mathrm{a}}$ & $6.1 \pm 0.2^{\mathrm{a}}$ & $6.1 \pm 0.2^{\mathrm{a}}$ \\
\hline
\end{tabular}

Means \pm standard deviation. Different letters in the same line differ significantly ( $<<0.05)$ by the Tukey's test. C1, 100\% pork back fat and no added dietary fiber; C2, 50\% pork back fat and no added dietary fiber; FR3, 50\% pork back fat and 3\% fructooligosaccharide; FR6, 50\% pork back fat and 6\% fructooligosaccharide; IN3, 50\% pork back fat and 3\% inulin; IN6, $50 \%$ pork back fat and $6 \%$ inulin; OF3, $50 \%$ pork back fat and 3\% oat fiber; OF6, 50\% pork back fat and 6\% oat fiber; WF3, 50\% pork back fat and 3\% wheat fiber; WF6, 50\% pork back fat and $6 \%$ wheat fiber.

control shows $\mathrm{pH}$ values similar $(\mathrm{P}>0.05)$. The dietary fibers used did not influence $(\mathrm{P}>0.05)$ the $\mathrm{pH}$ of the low-fat beef burger during 90 days of frozen storage condition.

Fructooligosaccharide and inulin at 3 and $6 \%$ caused a reduction in $\mathrm{L}^{\star}$ values $(\mathrm{P}<0.05)$ of low-fat beef burger (Table 3$)$. The insoluble dietary fibers show $L^{*}$ values similar to $\mathrm{C} 1$ ( $\mathrm{P}>0.05)$. López-Vargas et al. (2014) reported no differences in $\mathrm{L}^{\star}$ value in pork burger added with albedo-fiber powder from yellow passion fruit, similarly Gök et al. (2011) showed similar results when they replaced the pork fat in low-fat beef burger with poppy seed flour. After 90 days of storage under freezing, the $\mathrm{L}^{\star}$ value of $\mathrm{C} 1$ was significantly higher $(P>0.05)$ than the other treatments.

The amount of pork back fat added in the low-fat beef burger did not affect $(\mathrm{P}>0.05)$ the $\mathrm{a}^{*}$ value and the $\mathrm{b}^{*}$ value. The oat and wheat insoluble fibers increased the $b^{*}$ value when compared to the soluble fibers fructooligosaccharide and inulin. For low-fat beef burger added inulin and wheat fiber at 3 and $6 \%$ level $a^{*}$ value decreased after 90 days of storage. However, fructooligosaccharide and oat fiber, at 3 and $6 \%$ level, did not affect the $\mathrm{a}^{*}$ value.

\subsection{Cooking properties}

Control (C2) and low-fat beef burger with added inulin at $6 \%$ level (IN6) the yield decreased $(\mathrm{P}>0.05)$ (Table 4$)$. The yields of low-fat beef burger with added soluble fibers (FR3, FR6, IN3 and IN6) show no difference from the control treatment (C2). Angiolillo et al. (2015) added 9g of inulin in beef burger and observed the lowest yield and the highest diameter reduction. The incorporation of insoluble oat and wheat fiber at $6 \%$ level improved the yield of cooked low-fat beef burger, and showed a significant difference $(\mathrm{P}>0.05)$ from the other treatments. The increase in the added amount of insoluble fibers (oat and wheat fiber) improved the yield of low-fat beef burger. Similar results were observed by Serdaroglu (2006) showed that the evaluated yield of beef burger with added oat flour as fat replacer increased with added amount of oat flour
(0; 2 and 4\%). Sánchez-Zapata et al. (2010) reported that the addition of tiger nut fiber in 5, 10 or $15 \%$ levels increased the yield of pork burger compare to the control.

López-Vargas et al. (2014) studied the quality characteristics of pork burger with yellow passion fruit albedo fiber added and observed an increase in the yield when more passion fruit co-products fiber was added. The opposite effect was observed in the shrinkage of low-fat beef burger with added dietary fiber and the control, showing a decrease in shrinkage when insoluble fibers were added at $6 \%$ level. In cooked low-fat beef burger with added dietary fibers all texture parameters studied were affected by the addition of dietary fibers, except for springiness. Hardness values (Table 4$)$ increased $(P>0.05)$ when wheat fiber was added in a level of $6 \%$. Hardness values were similar when the fat content was decreased with no added fibers (control). When inulin was added in 3\% level, the hardness was lower. Similar results were observed in yield (Table 4).

Similar results were obtained by Ulu (2004) studying the addition of wheat flour, whey protein and soy protein in cooked meatballs. According to results featured by Keenan et al. (2014), fat replacement in meat products may modify texture parameters compared to control. The results of texture parameters are very dependents on the type of the fiber used (López-Vargas et al., 2014). Cohesiveness decreased significantly $(\mathrm{P}<0.05)$ when insoluble fiber was added at $6 \%$ level. Similar results were reported by Barretto et al. (2015) when pork back fat was partially replaced by wheat fiber in bologna. Fat replacement in beef burger showed no effect in chewiness, thus $\mathrm{C} 1$ and $\mathrm{C} 2$ were not significantly different $(\mathrm{P}>0.05)$. When the concentration of dietary fiber is increase $3 \%$ to $6 \%$ in low fat beef burger, showed an increase in chewiness, except for inulin. Fructooligosaccharide and inulin soluble fibers decreased chewiness $(\mathrm{P}>0.05)$ when compared to the controls ( $\mathrm{C} 1$ and $\mathrm{C} 2)$.

There are not difference $(\mathrm{P}>0.05)$ in TBARS values on day 0 (Table 5), the results were between 0.09 a $0.23 \mathrm{mg}$ of malonaldehyde $\mathrm{kg}$ of sample ${ }^{-1}$. $\mathrm{C} 1$ shows the highest $(\mathrm{P}>0.05)$ TBARS value after 30, 60 and 90 days of storage under freezing 
Table 4. Cooking properties and Texture Profile Analysis (TPA) of cooked low-fat beef burger with dietary fibers and controls.

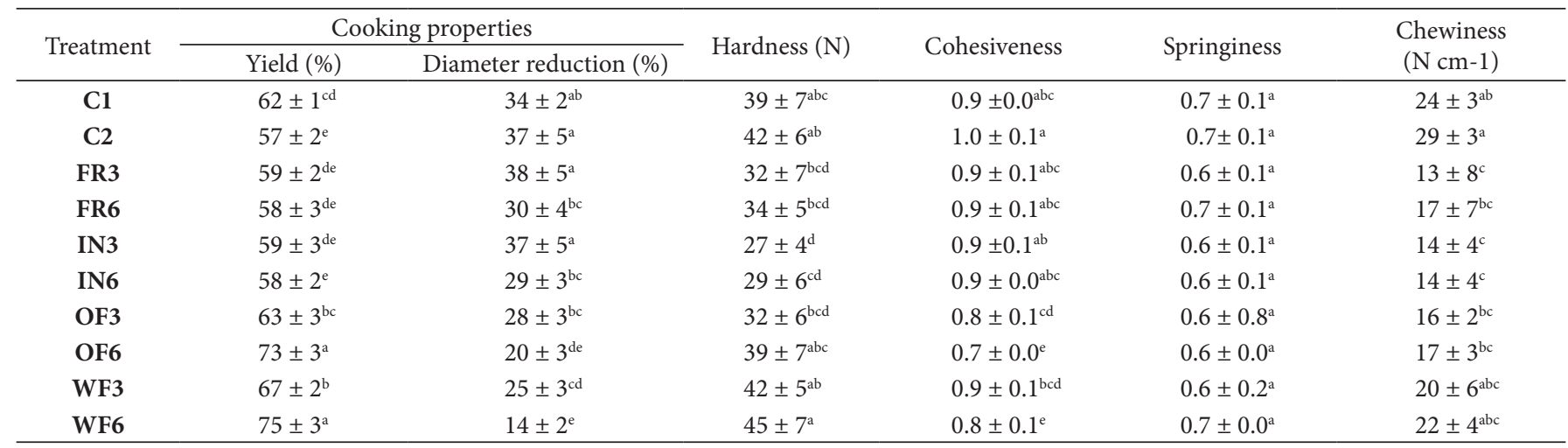

Means \pm standard desviation. Different letters in the same column differ significantly ( $\mathrm{P}<0.05)$ by the Tukey's test. C1, $100 \%$ pork back fat and no added dietary fiber; $\mathrm{C} 2,50 \%$ pork back fat and no added dietary fiber; FR3, 50\% pork back fat and 3\% fructooligosaccharide; FR6, 50\% pork back fat and 6\% fructooligosaccharide; IN3, 50\% pork back fat and 3\% inulin; IN6, 50\% pork back fat and 6\% inulin; OF3, 50\% pork back fat and 3\% oat fiber; OF6, 50\% pork back fat and 6\% oat fiber; WF3, 50\% pork back fat and 3\% wheat fiber; WF6, $50 \%$ pork back fat and $6 \%$ wheat fiber.

Table 5. TBARS values of low-fat beef burger with dietary fibers and controls, during storage (0, 30, 60 and 90 days).

\begin{tabular}{cllll}
\hline Treatment & 0 Day & 30 Days & 60 Days & 90 Days \\
\hline C1 & $0.2 \pm 0.1^{\mathrm{a}}$ & $0.6 \pm 0.0^{\mathrm{a}}$ & $0.7 \pm 0.1^{\mathrm{a}}$ & $0.9 \pm 0.0^{\mathrm{a}}$ \\
C2 & $0.2 \pm 0.0^{\mathrm{a}}$ & $0.1 \pm 0.0^{\mathrm{b}}$ & $0.2 \pm 0.0^{\mathrm{b}}$ & $0.1 \pm 0.0^{\mathrm{c}}$ \\
FR3 & $0.2 \pm 0.0^{\mathrm{a}}$ & $0.2 \pm 0.0^{\mathrm{b}}$ & $0.2 \pm 0.0^{\mathrm{b}}$ & $0.2 \pm 0.1^{\mathrm{c}}$ \\
FR6 & $0.2 \pm 0.0^{\mathrm{a}}$ & $0.1 \pm 0.0^{\mathrm{b}}$ & $0.2 \pm 0.0^{\mathrm{b}}$ & $0.1 \pm 0.0^{\mathrm{c}}$ \\
IN3 & $0.2 \pm 0.0^{\mathrm{a}}$ & $0.1 \pm 0.0^{\mathrm{b}}$ & $0.2 \pm 0.0^{\mathrm{b}}$ & $0.1 \pm 0.0^{\mathrm{c}}$ \\
IN6 & $0.2 \pm 0.0^{\mathrm{a}}$ & $0.1 \pm 0.0^{\mathrm{b}}$ & $0.1 \pm 0.0^{\mathrm{b}}$ & $0.1 \pm 0.0^{\mathrm{c}}$ \\
OF3 & $0.2 \pm 0.1^{\mathrm{a}}$ & $0.1 \pm 0.0^{\mathrm{b}}$ & $0.2 \pm 0.0^{\mathrm{b}}$ & $0.4 \pm 0.0^{\mathrm{b}}$ \\
OF6 & $0.1 \pm 0.0^{\mathrm{a}}$ & $0.1 \pm 0.0^{\mathrm{b}}$ & $0.1 \pm 0.0^{\mathrm{b}}$ & $0.4 \pm 0.1^{\mathrm{b}}$ \\
WF3 & $0.2 \pm 0.1^{\mathrm{a}}$ & $0.1 \pm 0.0^{\mathrm{b}}$ & $0.1 \pm 0.0^{\mathrm{b}}$ & $0.4 \pm 0.0^{\mathrm{b}}$ \\
WF6 & $0.1 \pm 0.0^{\mathrm{a}}$ & $0.2 \pm 0.0^{\mathrm{b}}$ & $0.4 \pm 0.1^{\mathrm{b}}$ & \\
\hline
\end{tabular}

Means \pm standard desviation. Different letters in the same column differ significantly $(\mathrm{P}<0.05)$ by the Tukey's test. C1, $100 \%$ pork back fat and no added dietary fiber; $\mathrm{C} 2,50 \%$ pork back fat and no added dietary fiber; FR3, 50\% pork back fat and 3\% fructooligosaccharide; FR6, 50\% pork back fat and 6\% fructooligosaccharide; IN3, 50\% pork back fat and 3\% inulin; IN6, $50 \%$ pork back fat and 6\% inulin; OF3, $50 \%$ pork back fat and $3 \%$ oat fiber; OF6, 50\% pork back fat and $6 \%$ oat fiber; WF3, 50\% pork back fat and $3 \%$ wheat fiber; WF6, $50 \%$ pork back fat and $6 \%$ wheat fiber.

conditions, reaching values near to $0.6 \mathrm{mg}$ of malonaldehyde $\mathrm{kg}$ of sample $\mathrm{e}^{-1}$. It showed that the dietary fibers, in replace with various concentrations added to the low-fat beef burger did not affect the lipid oxidation. This result is similar to Santos et al. (2012) who reported that the partial replacement of pork fat in fermented sausage using fructooligosaccharide does not affect the lipid oxidation. Different results were found by Cava et al. (2012) when added 3\% of inulin in cooked chicken products obtained higher TBARS value than the control, without addition of fiber. The authors also report that inulin modified texture properties of the final product. After 90 days of storage under freezing, the low-fat beef burger added with soluble fibers showed lower TBARS value $(\mathrm{P}>0.05)$ in compared to low-fat beef burger added with insoluble fibers.

\subsection{Microbiological analysis}

The microbiological analysis (data not shown) revealed that all the treatments were within the limits established by Brazilian Legislation (Brazilian Health Surveillance Agency).
The microbial counts were $<100 \mathrm{MPN} \mathrm{g}^{-1}$ for thermotolerant coliforms, $<10 \mathrm{CFU} \mathrm{g}^{-1}$ of sulfite-reducing clostridia, $<100 \mathrm{CFU} \mathrm{g}^{-1}$ of Coagulase-Positive Staphylococci, and absence of Salmonella in $25 \mathrm{~g}$. According to these results, all the treatments of low fat beef burger and control were safe for consumption from a microbiological standpoint.

\subsection{Sensory analysis}

Scores for color attributes (Table 6) were lower when insoluble fiber (wheat and oat fiber) at $6 \%$ level was added and it showed difference $(\mathrm{P}<0.05)$ in compared to low-fat beef burger with added soluble fibers and control. For the flavor attribute, none the treatments showed difference $(\mathrm{P}>0.05)$ from $\mathrm{C} 1$. Similar results were reported by Alesón-Carbonell et al. (2005) who added several types of lemon albedo in beef burger and Mansour \& Khalil (1999) who replaced kidney fat in beef burger using three types of hydrated wheat fiber.

The treatment with added $6 \%$ of oat fiber (OF6) showed the lowest score for color attribute, indicating that when this 
Table 6. Sensory results of low-fat beef burgers with dietary fibers and controls.

\begin{tabular}{ccccc}
\hline Treatments & Color & Taste & Texture & Overall acceptance \\
\hline C1 & $6.6 \pm 1.9^{\mathrm{ab}}$ & $6.2 \pm 2.1^{\mathrm{ab}}$ & $6.5 \pm 2.0^{\mathrm{ab}}$ & $6.3 \pm 2.0^{\mathrm{abc}}$ \\
C2 & $7.2 \pm 1.3^{\mathrm{ab}}$ & $6.8 \pm 1.4^{\mathrm{a}}$ & $7.1 \pm 1.6^{\mathrm{a}}$ & $7.0 \pm 1.3^{\mathrm{a}}$ \\
FR3 & $6.9 \pm 1.8^{\mathrm{ab}}$ & $6.7 \pm 1.8^{\mathrm{a}}$ & $6.9 \pm 1.7^{\mathrm{a}}$ & $6.8 \pm 1.7^{\mathrm{ab}}$ \\
FR6 & $6.5 \pm 1.8^{\mathrm{ab}}$ & $6.7 \pm 1.8^{\mathrm{a}}$ & $6.8 \pm 1.8^{\mathrm{ab}}$ & $6.8 \pm 1.7^{\mathrm{ab}}$ \\
IN3 & $7.0 \pm 1.7^{\mathrm{ab}}$ & $6.8 \pm 1.6^{\mathrm{a}}$ & $7.2 \pm 1.5^{\mathrm{a}}$ & $6.7 \pm 1.6^{\mathrm{ab}}$ \\
IN6 & $7.3 \pm 1.5^{\mathrm{a}}$ & $7.0 \pm 1.6^{\mathrm{a}}$ & $5.9 \pm 1.5^{\mathrm{bc}}$ & $7.0 \pm 1.4^{\mathrm{a}}$ \\
OF3 & $6.8 \pm 1.6^{\mathrm{ab}}$ & $6.2 \pm 1.9^{\mathrm{ab}}$ & $4.8 \pm 2.0^{\mathrm{b}}$ & $6.0 \pm 1.9^{\mathrm{bcd}}$ \\
OF6 & $5.6 \pm 1.9^{\mathrm{c}}$ & $5.4 \pm 2.0^{\mathrm{b}}$ & $6.0 \pm 2.0^{\mathrm{bc}}$ & $5.2 \pm 1.8^{\mathrm{d}}$ \\
WF3 & $6.3 \pm 1.9^{\mathrm{bc}}$ & $6.3 \pm 1.8^{\mathrm{ab}}$ & $5.2 \pm 2.2^{\mathrm{cd}}$ & $6.1 \pm 1.8^{\mathrm{abc}}$ \\
WF6 & $5.5 \pm 2.1^{\mathrm{c}}$ & $6.2 \pm 1.9^{\mathrm{ab}}$ & $5.6 \pm 1.9^{\mathrm{cd}}$ \\
\hline
\end{tabular}

Means \pm standard desviation. Different letters in the same column differ significantly ( $<<0.05)$ by the Tukey's test. C1, $100 \%$ pork back fat and no added dietary fiber; C2, 50\% pork back fat and no added dietary fiber; FR3, 50\% pork back fat and 3\% fructooligosaccharide; FR6, 50\% pork back fat and 6\% fructooligosaccharide; IN3, 50\% pork back fat and 3\% inulin; IN6, $50 \%$ pork back fat and $6 \%$ inulin; OF3, $50 \%$ pork back fat and $3 \%$ oat fiber; OF6, $50 \%$ pork back fat and $6 \%$ oat fiber; WF3, 50\% pork back fat and $3 \%$ wheat fiber; WF6, $50 \%$ pork back fat and $6 \%$ wheat fiber.
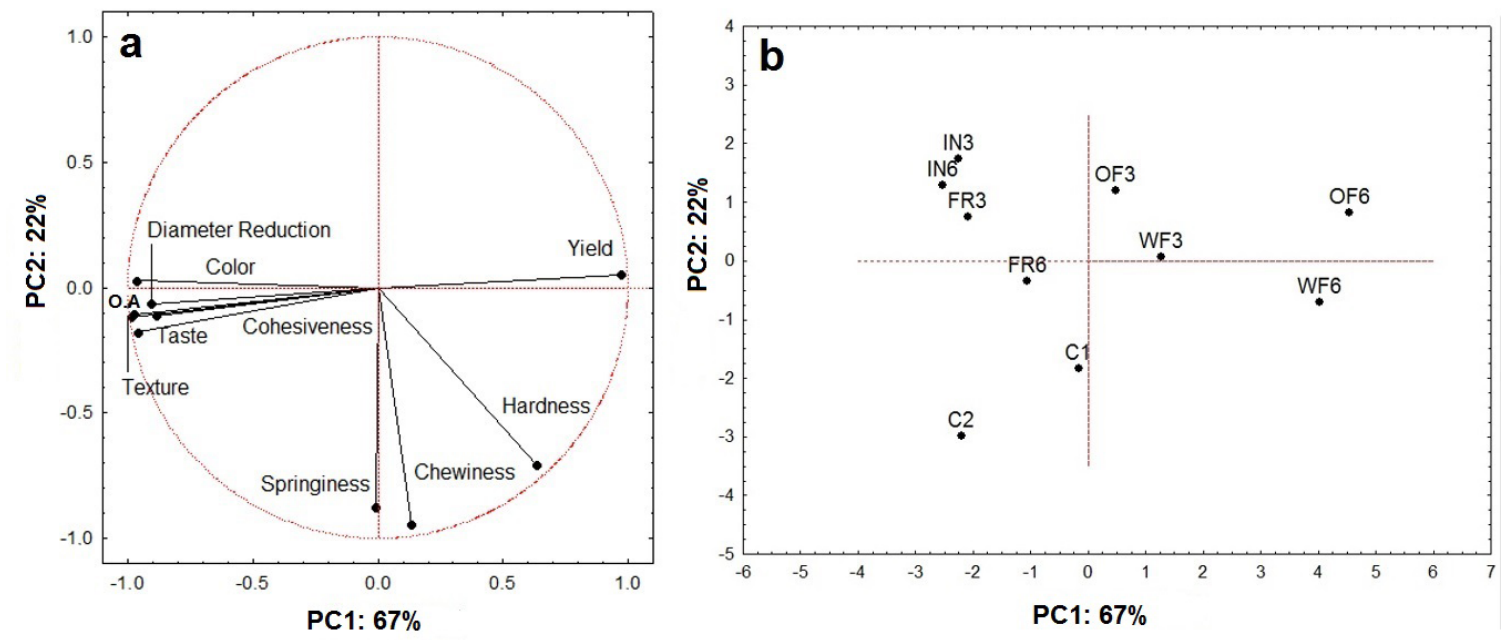

Figure 1. Principal component analysis of technologic and sensory attributes (a) related to control beef burger and low-fat beef burger with added dietary fibers (b).

C1, 100\% pork back fat and no added dietary fiber; C2, 50\% pork back fat and no added dietary fiber; FR3, 50\% pork back fat and $3 \%$ fructooligosaccharide; FR6, 50\% pork back fat and 6\% fructooligosaccharide; IN3, 50\% pork back fat and 3\% inulin; IN6, 50\% pork back fat and $6 \%$ inulin; OF $3,50 \%$ pork back fat and $3 \%$ oat fiber; OF6, $50 \%$ pork back fat and $6 \%$ oat fiber; WF3, 50\% pork back fat and $3 \%$ wheat fiber; WF6, $50 \%$ pork back fat and $6 \%$ wheat fiber.

fiber is added at $6 \%$ level the color of beef burger is negatively affected. Texture score decreased when insoluble fiber was added at $6 \%$ level and they were different $(\mathrm{P}<0.05)$ from the control (C1). These results are in agreement with the hardness, when the wheat fiber at $6 \%$ level showed a high score, indicating that lower score represented high hardness. The lowest over all acceptance score was observed when the wheat fiber was added at $6 \%$ level and it was different $(\mathrm{P}<0.05)$ from the control $(\mathrm{C} 1)$. Similar results were reported by Besbes et al. (2007), when they partially replaced the meat in beef burger by pea fiber and wheat fiber. Inulin used in $6 \%$ level in low-fat beef burger showed the highest score for all the sensory attributes.

\subsection{Correlation}

Principal component analysis of the cooked low-fat beef burger added with dietary fibers and control showed that the first principal component (PC1) explained $67 \%$ of the data variation and the second principal component (PC2) explained $22 \%$, thus totaling $89 \%$ (Figure 1 ).

The variables that explained PC1 were yield (right area), sensory attributes (color, taste, texture and overall acceptance), diameter reduction and cohesiveness (left area). Correlation analysis showed that variables of the same group have a strong positive correlation $(\mathrm{P}<0.05)$. While other variables showed 
strong negative correlation $(\mathrm{P}<0.05)$ with others variables. The texture profile parameters were strongly represented in PC2, accounted for a combination of variables including hardness, springiness and chewiness. Overall acceptance and texture profile analysis parameters were positively related $(\mathrm{P}<0.05)$ indicating a correlation between the texture of the cooked low-fat beef burger with added dietary fibers and its acceptance. Hardness showed no correlation $(\mathrm{P}>0.05)$ with others variables. Cohesiveness showed a strong negative correlation $(\mathrm{P}>0.05)$ with yield and a positive strong correlation $(\mathrm{P}<0.05)$ with diameter reduction.

\section{Conclusion}

The use of soluble and insoluble dietary fibers has different effects on the performance: the insoluble fiber increased the yield, hardness, cohesiveness and springiness of low-fat beef burger while the soluble fiber increased the acceptance of the sensory attributes, especially when inulin fiber at $6 \%$ was added. The incorporation of $6 \%$ insoluble oat or wheat fiber decreased shrinkage of low-fat beef burgers but reduced overall impression. Adding inulin at $6 \%$ was the best alternative in low-fat beef burger.

\section{Acknowledgements}

The authors would like to thank CNPQ (Conselho Nacional de Desenvolvimento Científico e Tecnológico) and CAPES (Coordenação de Aperfeiçoamento de Pessoal de Nível Superior) for financial support.

\section{References}

Alesón-Carbonell, L., Fernández-López, J., Pérez-Álvarez, J. A., \& Kuri, V. (2005). Characteristics of beef burger as influenced by various types of lemon albedo. Innovative Food Science \& Emerging Technologies, 6(2), 247-255. http://dx.doi.org/10.1016/j.ifset.2005.01.002.

Álvarez, D., \& Barbut, S. (2013). Effect of inulin, $\beta$-glucan and their mixtures on emulsion stability, color and textural parameters of cooked meat batters. Meat Science, 94(3), 320-327. http://dx.doi. org/10.1016/j.meatsci.2013.02.011. PMid:23567131.

Angiolillo, L., Conte, A., \& Del Nobile, M. A. (2015). Technological strategies to produce functional meat burgers. LebensmittelWissenschaft + Technologie, 62(1), 697-703. http://dx.doi.org/10.1016/j. lwt.2014.08.021.

Barretto, A. C. S., Pacheco, M. T. B., \& Pollonio, M. A. R. (2015). Effect of the addition of wheat fiber and partial pork back fat on the chemical composition, texture and sensory property of low-fat bologna sausage containing inulin and oat fiber. Food Science and Technology, 35(1), 100-107. http://dx.doi.org/10.1590/1678-457X.6496.

Besbes, S., Attia, H., Deroanne, C., Makni, S., \& Blecker, C. (2007). Partial replacement of meat by pea fiber and wheat fiber: effect on the chemical composition, cooking characteristics and sensory properties of beef burgers. Journal of Food Quality, 31(4), 480-489. http://dx.doi.org/10.1111/j.1745-4557.2008.00213.x.

Bligh, E. G., \& Dyer, W. J. (1959). A rapid method of total lipid extraction and purification. Canadian Journal of Biochemistry and Physiology, 37(8), 911-917. http://dx.doi.org/10.1139/o59-099. PMid:13671378.

Brasil, Ministério da Agricultura, Pecuária e Abastecimento. Secretaria de Defesa Agropecuária. (2000, 31 de julho). Aprova o regulamento técnico de identidade e qualidade de hambúrguer (Instrução Normativa n² 20, de 31 de julho de 2000). Diário Oficial da União.
Borderías, A. J., Sánchez-Alonso, I., \& Pérez-Mateos, M. (2005). New applications of fibres in foods: addition to fishery products. Trends in Food Science \& Technology, 16(10), 458-465. http://dx.doi. org/10.1016/j.tifs.2005.03.011.

Bourne, M. C. (2002). Food texture and viscosity: concept and measurement (2nd ed., Chap. 4). New York: Academic Press.

Cava, R., Ladero, L., Cantero, V., \& Rosario Ramírez, M. (2012). Assessment of different dietary fibers (tomato fiber, beet root fiber, and inulin) for the manufacture of chopped cooked chicken products. Journal of Food Science, 77(4), C346-C352. http://dx.doi. org/10.1111/j.1750-3841.2011.02597.x. PMid:22352766.

Cofrades, S., Benedí, J., Garcimartin, A., Sánchez-Muniz, F. J., \& JimenezColmenero, F. (2016). A comprehensive approach to formulation of seaweed-enriched meat products: From technological development to assessment of healthy properties. Food research international, 99(Pt 3), 1084-1094.PMid:28865619.

Decker, E. A., \& Park, Y. (2010). Healthier meat products as functional foods. Meat Science, 86(1), 49-55. http://dx.doi.org/10.1016/j. meatsci.2010.04.021. PMid:20580991.

Drzikova, B., Dongowski, G., Gebhardt, E., \& Habel, A. (2005). The composition of dietary fibre-riche extrudates from oat effects from oat affects bile acid binding and fermentation in vitro. Food Chemistry, 90(1-2), 181-192. http://dx.doi.org/10.1016/j.foodchem.2004.03.041.

Elleuch, M., Bedigian, D., Roiseux, O., Besbes, S., Blecker, C., \& Attia, H. (2011). Dietary fibre and fibre-rich by-products of food processing: characterization, technological functionality and commercial applications. Food Chemistry, 124(2), 411-421. http:// dx.doi.org/10.1016/j.foodchem.2010.06.077.

Fernández-Ginés, J. M., Fernández-López, J., Sayas-Barberá, E., Sendra, E., \& Pérez-Alvarez, J. A. (2004). Lemon albedo as a new source of dietary fiber: application to bologna sausage. Meat Science, 67(1), 7-13. http://dx.doi.org/10.1016/j.meatsci.2003.08.017. PMid:22061110.

Gök, V., Akkaya, L., Obuz, E., \& Bulut, S. (2011). Effect of ground poppy seed as a fat replacer on meat burgers. Meat Science, 89(4), 400-404. http://dx.doi.org/10.1016/j.meatsci.2011.04.032. PMid:21620577.

Hauly, M. C. O., \& Moscatto, J. A. (2002). Inulin and Oligofructosis: a review about functional properties, prebiotic effects and importance for food industry. Semina: Ciências Exatas e Tecnológicas, 23(1), 105-118.

Horwitz, W., \& Latimer, G. W. (2007). Official Methods of Analysis (18th ed.). Gaithersburg: AOAC International.

Huang, S. C., Tsai, Y. F., \& Chen, C. M. (2011). Effects of wheat fiber, oat fiber, and inulin on sensory and physic-chemical properties of Chinese-style sausages. Asian-Australasian Journal of Animal Sciences, 24(6), 875-880. http://dx.doi.org/10.5713/ajas.2011.10317.

Keenan, D. F., Resconi, V. C., Kerry, J. P., \& Hamill, R. M. (2014). Modelling the influence of inulin as a fat substitute in comminuted meat products on their physico-chemical characteristics and eating quality using a mixture design approach. Meat Science, 96(3), 13841394. http://dx.doi.org/10.1016/j.meatsci.2013.11.025. PMid:24361558.

López-Vargas, J. H., Fernández-López, J., Pérez-Álvarez, J. A., \& ViudaMartos, M. (2014). Quality characteristics of pork burger added with albedo-fiber powder obtained from yellow passion fruit (Passiflora edulis var.flavicarpa) co-products. Meat Science, 97(2), 270-276. http://dx.doi.org/10.1016/j.meatsci.2014.02.010. PMid:24607997.

Mansour, E. H., \& Khalil, A. H. (1999). Characteristics of low-fat beefburgers as influenced by various types of wheat fibres. Journal of the Science of Food and Agriculture, 79(1), 493-498. http:// dx.doi.org/10.1002/(SICI)1097-0010(19990315)79:4<493::AIDJSFA4 $>3.0 . C O ; 2-5$. 
Piñero, M. P., Parra, K., Huerta-Leidenz, N., Arenas de Moreno, L., Ferrer, M., Araujo, S., \& Barboza, Y. (2008). Effect of oat's soluble fibre ( $\beta$-glucan) as a fat replacer on physical, chemical, microbiological and sensory properties of low-fat beef patties. Meat Science, 80(3), 675680. http://dx.doi.org/10.1016/j.meatsci.2008.03.006. PMid:22063581.

Saldaña, E., Lemos, A. L. S. C., Selani, M. M., Spada, F. P., Almeida, M. A., \& Contreras-castillo, C. J. (2014). Influence of animal fat substitution by vegetal fat on Mortadella-type products formulated with different hydrocolloids. Scientia Agrícola, 72(6), 495-503. http:// dx.doi.org/10.1590/0103-9016-2014-0387.

Sánchez-Zapata, E., Muñoz, C. M., Fuentes, E., Fernández-López, J., Sendra, E., Sayas, E., Navarro, C., \& Pérez-Alvarez, J. A. (2010). Effect of tiger nut fiber on quality characteristics of pork burger. Meat Science, 85(1), 70-76. http://dx.doi.org/10.1016/j.meatsci.2009.12.006. PMid:20374867.

Santos, B. A., Campagnol, P. C. B., Pacheco, M. T. B., \& Pollonio, M. A. R. (2012). Fructooligosaccharides as a fat replacer in fermented cooked sausages. International Journal of Food Science \& Technology, 47(6), 1183-1192. http://dx.doi.org/10.1111/j.1365-2621.2012.02958.x.

Selani, M. M., Shirado, A. N., Margiotta, G. B., Saldaña, E., Spada, F. P., Piedade, S. M. S., Contreras-Castillo, C. J., \& Canniatti-Brazaca, S. G. (2016). Effects of pineapple byproduct and canola oil as fat replacers on physicochemical and sensory qualities of low-fat beef burger. Meat Science, 112(1), 69-76. http://dx.doi.org/10.1016/j. meatsci.2015.10.020. PMid:26562792.

Serdaroglu, M. (2006). The characteristics of beef patties containing different levels of fat and oat flour. International Journal of Food Science \& Technology, 41(2), 147-153. http://dx.doi.org/10.1111/ j.1365-2621.2005.01041.x.

Schmiele, M., Mascarenhas, M. C. C. N., Barretto, A. C. S., \& Pollonio, M. A. R. (2015). Dietary fiber as fat substitute in emulsified and cooked meat model system. Lebensmittel-Wissenschaft + Technologie, 61(1), 105-111. http://dx.doi.org/10.1016/j.lwt.2014.11.037.

Shariati-Ievari, S., Ryland, D., Edel, A., Nicholson, T., Suh, M., \& Aliani, M. (2016). Sensory and physicochemical studies of thermally micronized chickpea (cicer arietinum) and green lentil (lens culinaris) flours as binders in low-fat beef burgers. Journal of Food Science, 81(5), S1230-S1242. http://dx.doi.org/10.1111/1750-3841.13273. PMid:26990186.

Talukder, S. (2015). Effect of dietary fiber on properties and acceptance of meat products: a review. Critical Reviews in Food Science and Nutrition, 55(7), 1005-1011. http://dx.doi.org/10.1080/10408398. 2012.682230. PMid:24915339.

Tapp, W. N. 3rd, Yancey, J. W. S., \& Apple, J. K. (2011). How is the instrumental color of meat measure? Meat Science, 89(1), 1-5. http://dx.doi.org/10.1016/j.meatsci.2010.11.021. PMid:21546168.

Ulu, H. (2004). Effect of wheat flour, whey protein concentrate and soya protein isolate on oxidative processes and texture properties of cooked meatballs. Food Chemistry, 87(4), 523-529. http://dx.doi. org/10.1016/j.foodchem.2004.01.002.

Verma, A. K., \& Banerjee, R. (2010). Dietary fibre as functional ingredient in meat products: a novel approach for healthy living: a review. Journal of Food Science and Technology, 47(3), 247-257. http://dx.doi.org/10.1007/s13197-010-0039-8. PMid:23572633.

Vyncke, W. (1970). Direct determination of the thiobarbituric acid value in trichloracetic acid extracts of fish as a measure of oxidative rancidity. European Journal of Lipid Science and Technology, 72(12), 1084-1087.

Yoo, S. S., Kook, S. H., Park, S. Y., Shim, J. H., \& Chin, K. B. (2007). Physicochemical characteristics, textural properties and volatile compounds in comminuted sausages as affected by various fat levels and fat replacers. International Journal of Food Science \& Technology, 42(9), 1114-1122. http://dx.doi.org/10.1111/j.1365-2621.2006.01402.x.

Weiss, J., Gibis, M., Schuh, V., \& Salminen, H. (2010). Advances in ingredient and processing systems for meat and meat products. Meat Science, 86(1), 196-213. http://dx.doi.org/10.1016/j.meatsci.2010.05.008. PMid:20619800. 